Check for updates

Cite this: RSC Adv., 2017, 7, 38659

Received 3rd June 2017

Accepted 26th July 2017

DOI: 10.1039/c7ra06181a

rsc.li/rsc-advances

\section{In situ-DRIFTS study: influence of surface acidity of rhenium-based catalysts in the metathesis of various olefins for propylene production}

\author{
Siriporn Vorakitkanvasin, ${ }^{a}$ Weena Phongsawat, ${ }^{\mathrm{b}}$ Kongkiat Suriye, ${ }^{\mathrm{b}}$ \\ Piyasan Praserthdam ${ }^{a}$ and Joongjai Panpranot (iD *a
}

\begin{abstract}
Various olefins including 1- and 2-butene, 2-pentene, and ethylene were used as the reactants for producing propylene by self- and cross-metathesis reactions at $60{ }^{\circ} \mathrm{C}$ on supported Re-based catalysts (4 wt\% Re). A similar surface structure of rhenium oxides in the form of isolated $\mathrm{ReO}_{4}$ species was observed on $\mathrm{Al}_{2} \mathrm{O}_{3}$ and $\mathrm{SiO}_{2}-\mathrm{Al}_{2} \mathrm{O}_{3}$ supported rhenium oxide catalysts. The catalysts, however, differed in terms of the types (Lewis/Bronsted) and strengths of the acidic sites, as revealed by ammonia temperature programmed desorption $\left(\mathrm{NH}_{3}-\mathrm{TPD}\right)$ and in situ diffuse reflectance infrared Fourier transform spectroscopy (in situ DRIFTS) of $\mathrm{NH}_{3}$ adsorption and thermodesorption results. Weak Lewis acidity, especially high ratios of Lewis acid bands at $1280 \mathrm{~cm}^{-1} / 1622 \mathrm{~cm}^{-1}$, led to high metathesis activity of the Re-based catalysts. The additional isomerization activity, however, required strong Bronsted acid sites. The product distribution from the various feeds depended largely on the size of the olefins, and not only on the acid properties of the catalysts. $\mathrm{Re}_{2} \mathrm{O}_{7} / \mathrm{SiO}_{2}-\mathrm{Al}_{2} \mathrm{O}_{3}$ appeared to be a versatile catalyst for obtaining a high yield of propylene using either a single reactant (1- or 2-butene) or an ethylene mixed feed.
\end{abstract}

\section{Introduction}

Propylene is one of the major feedstocks in the petrochemical industry used to produce various chemical intermediates and polymers. Since propylene demand is expected to continue to grow, on-purpose propylene production technology, such as olefin metathesis, is becoming an increasingly important reaction for propylene supply. ${ }^{\mathbf{1}}$ Metathesis of ethylene and 2-butene to propylene is typically carried out over heterogeneous catalysts based on tungsten oxide, molybdenum oxide, and rhenium oxide. ${ }^{2-4}$ Rhenium oxide-based catalysts are of interest because of their high activity and selectivity for olefin metathesis at low reaction temperatures. ${ }^{3}$ The typical supports used for preparation of highly dispersed rhenium oxide catalysts are alumina and silica-alumina., ${ }^{3,5-7}$

Surface structures of the active isolated $\mathrm{ReO}_{4}$ species on alumina have been identified by a number of studies based on Raman, in situ Raman, and in situ IR spectroscopy. ${ }^{8-13}$ The surface rhenium oxide species presented on silica-alumina support were similar to those of alumina supported ones but they were inactive on the $\mathrm{Si}-\mathrm{OH} .{ }^{\mathbf{1 4}}$ Besides, the catalytic performances of supported rhenium oxide-based catalysts have

${ }^{a}$ Center of Excellence on Catalysis and Catalytic Reaction Engineering, Department of Chemical Engineering, Faculty of Engineering, Chulalongkorn University, Bangkok 10330, Thailand. E-mail: joongjai.p@chula.ac.th; Fax: +66-2218-6877; Tel: +662218-6869

${ }^{b}$ SCG Chemicals Co., Ltd, 1Siam-cement Rd, Bang sue, Bangkok 10800, Thailand often been correlated to either Bronsted ${ }^{\mathbf{1 5}}$ or Lewis acid sites. ${ }^{\mathbf{1 6}}$ Bouchmella et $a l .{ }^{17}$ used a nonhydrolytic sol-gel method (NHSG) to prepare highly active $\mathrm{Re}-\mathrm{Si}-\mathrm{Al}$ metathesis catalysts. The most active NHSG catalyst in the cross-metathesis of ethylene and butene to propylene was found on the catalysts containing the highest amount of acidic sites with well dispersed rhenium oxide species and high surface areas. A recent study from our group ${ }^{\mathbf{1 1}}$ showed that the higher acidic $\mathrm{OH}$ group on the alumina support provided higher Lewis acid sites necessary for the formation of the rhenium oxide active species whereas the higher Bronsted acidity led to higher amount of coke and $\mathrm{C}_{5+}$ products. In addition, the acid strength of Lewis acid sites appeared to be another important factor determining metathesis activity of supported $\mathrm{Re}_{2} \mathrm{O}_{7}$ catalysts.

Due to olefins price fluctuation, nowadays ethylene price is getting higher than propylene, ${ }^{18}$ therefore, other reactants such as butene and pentene are considered as alternative reactants for metathesis reaction for propylene production. This work aims to define the catalyst properties especially the types (Lewis or Bronsted) and the strength of the acidic sites on supported rhenium oxide-based catalysts that could provide high yield of propylene from different feedstocks. Production of propylene via the metathesis of ethylene and 2-butene, ethylene and 2-pentene, pure 2-butene, pure 1-butene, and pure 2-pentene was obtained over the low rhenium loading catalysts ( $4 \mathrm{wt} \% \mathrm{Re}$ ) supported on silica and silica-alumina. The surface structures of rhenium oxide species were determined by Raman microscopy. The types and the strength of acidity on the catalyst 
surface were identified by ammonia temperature programmed desorption ( $\left.\mathrm{NH}_{3}-\mathrm{TPD}\right)$ and in situ diffuse reflectance infrared Fourier transform spectroscopy (in situ DRIFTS) of $\mathrm{NH}_{3}$ adsorption and thermodesorption.

\section{Experimental}

\subsection{Catalyst preparation}

Supported rhenium oxide catalysts with $4 \mathrm{wt} \%$ rhenium loading were prepared by the incipient wetness impregnation method using an aqueous solution of ammonium perrhenate $\left(\mathrm{NH}_{4} \mathrm{ReO}_{4}\right.$, Aldrich). The supports were impregnated several times to obtain the $4 \mathrm{wt} \%$ of rhenium loading. Between impregnation steps, the catalysts were held for $2 \mathrm{~h}$ at room temperature and then dried at $110{ }^{\circ} \mathrm{C}$ for $12 \mathrm{~h}$. After the impregnation step, the catalysts were calcined in dry air at $550{ }^{\circ} \mathrm{C}$ for $8 \mathrm{~h}$. For comparison purposes, commercial $\gamma-\mathrm{Al}_{2} \mathrm{O}_{3}$ (Fluka) and $\mathrm{SiO}_{2}-\mathrm{Al}_{2} \mathrm{O}_{3}$ (Grade 135, Aldrich) were employed as the support for the preparation of $\mathrm{Re}_{2} \mathrm{O}_{7} / \gamma-\mathrm{Al}_{2} \mathrm{O}_{3}$ and $\mathrm{Re}_{2} \mathrm{O}_{7} /$ $\mathrm{SiO}_{2}-\mathrm{Al}_{2} \mathrm{O}_{3}$ catalysts. The catalysts were denoted as $\mathrm{Re} / \mathrm{Al}$ and $\mathrm{Re} / \mathrm{SiO}_{2}-\mathrm{Al}_{2} \mathrm{O}_{3}$, respectively. The ANN support was prepared by calcination of aluminium nitrate $\left(\mathrm{Al}\left(\mathrm{NO}_{3}\right)_{3} \cdot 9 \mathrm{H}_{2} \mathrm{O}\right)$ under air at $550{ }^{\circ} \mathrm{C}$ for $4 \mathrm{~h}$. The rhenium catalyst on ANN was denoted as Re/ ANN. According our previous paper, the use of alumina support prepared from ANN calcined at $550{ }^{\circ} \mathrm{C}$ led to the formation of higher amount of the second rhenium oxide species and improved catalytic performances in the metathesis of ethylene and 2-pentene than the conventional $\mathrm{Re}_{2} \mathrm{O}_{7} / \gamma-\mathrm{Al}_{2} \mathrm{O}_{3}{ }^{11}$

\subsection{Catalyst characterization}

The surface structures of rhenium oxide species were examined by Raman microscopy under ambient conditions using a Senterra Dispersive Raman microscopy equipped with the visible laser at $532 \mathrm{~nm}$ and a TE-cooled CCD detector. The amount of acidity on catalyst surface was measured by the $\mathrm{NH}_{3}$-TPD in a quartz U-tube reactor. Firstly, approximately $0.10 \mathrm{~g}$ catalyst sample was pretreated in a helium gas flow $\left(25 \mathrm{~mL} \mathrm{~min}^{-1}\right)$ at $500{ }^{\circ} \mathrm{C}$ for $1 \mathrm{~h}$ and then cooled down to $40{ }^{\circ} \mathrm{C}$. After that, the sample was saturated with $15 \% \mathrm{NH}_{3} / \mathrm{He}$. The physisorbed ammonia was desorbed in a helium gas flow for about $2 \mathrm{~h}$. Finally, the sample was heated up from 40 to $500{ }^{\circ} \mathrm{C}$ at a heating rate $10{ }^{\circ} \mathrm{C} \mathrm{min}^{-1}$. The amount of ammonia in effluent was recorded via TCD signal and analyzed with a Micromeritic Chemisorb 2750 automated system (ChemiSoftTPx software). The in situ diffuse reflectance infrared Fourier transform spectroscopy (DRIFTS) of $\mathrm{NH}_{3}$ adsorption spectra were recorded with a Bruker Vertex-70 FT-IR spectrometer equipped with a Harrick Praying Mantis attachment for diffuse reflectance spectroscopy. About 20-25 mg of sample was placed in a Harrick cell, which were cooled by flowing water. Then, the sample was dehydrated at a heating rate of $10{ }^{\circ} \mathrm{C} \min ^{-1}$ up to $500{ }^{\circ} \mathrm{C}$ and held for $1 \mathrm{~h}$ in a nitrogen gas flow. After that, the sample was cooled to $60{ }^{\circ} \mathrm{C}$. After pretreatment procedure, the sample was saturated with $15 \% \mathrm{NH}_{3} / \mathrm{He}$. After saturation, the physisorbed ammonia was desorbed in a nitrogen gas flow about $2 \mathrm{~h}$. Then, the sample was heated from $60{ }^{\circ} \mathrm{C}$ temperature to $500{ }^{\circ} \mathrm{C}$ at a heating rate $10{ }^{\circ} \mathrm{C} \min ^{-1}$. The spectra were collected using a MCT detector with a resolution of $4 \mathrm{~cm}^{-1}$ and an accumulation of 64 scans.

\subsection{Reaction test}

The performances of supported rhenium oxide catalysts were evaluated in the metathesis reactions using 2-pentene and ethylene $\left(2-\mathrm{C}_{5}+\mathrm{C}_{2}\right)$, pure 2-pentene $\left(2-\mathrm{C}_{5}\right), 2$-butene and ethylene $\left(2-\mathrm{C}_{4}+\mathrm{C}_{2}\right)$, pure 2-butene $\left(2-\mathrm{C}_{4}\right)$ and pure 1-butene $\left(1-\mathrm{C}_{4}\right)$ as the reactants. For the cross metathesis reaction (mixed feeds), an excess of the molar ratio of ethylene : 2-pentene and ethylene : 2-butene was used for the reaction tests. The reactants were mixed with high purity nitrogen in order to have the composition of $6 \mathrm{vol} \%$ of reactants in nitrogen balance. The reactions were carried out with a weight hourly space velocity (WHSV) $1.7 \mathrm{~h}^{-1}$ using $1.5 \mathrm{~g}$ catalyst in a fixed-bed reactor (ID tube $=15.8 \mathrm{~mm}$ ) under atmospheric pressure. Prior to the reaction, the catalyst was pretreated at $500{ }^{\circ} \mathrm{C}$ for $1 \mathrm{~h}$ and then cooled down to reaction temperature $60^{\circ} \mathrm{C}$ under nitrogen flow. During the reaction, both reactants and products were analyzed by an on-line Agilent 7820A gas chromatograph equipped with a GS-Gaspro 113-4362 capillary column, $0.32 \mathrm{~mm}$ diameter and $60 \mathrm{~m}$ in length. The GC signals were processed by an EZChrom Elite integrated peak program integrator.

\section{Results and discussion}

\subsection{Catalyst characterization}

The low loading Re oxide catalysts ( $4 \mathrm{wt} \% \mathrm{Re}$ ) in this study were prepared on three different supports including commercial $\gamma$-alumina $(\mathrm{Re} / \mathrm{Al})$, alumina obtained by calcination of aluminium nitrate at $550{ }^{\circ} \mathrm{C}(\mathrm{Re} / \mathrm{ANN})$, and commercial silicaalumina $\left(\mathrm{Re} / \mathrm{SiO}_{2}-\mathrm{Al}_{2} \mathrm{O}_{3}\right)$. All the catalysts exhibited similar Raman bands at 970, 920 and $325 \mathrm{~cm}^{-1}$ under ambient conditions, which were assigned to $\nu_{\mathrm{s}}(\mathrm{Re}=\mathrm{O}), \nu_{\mathrm{as}}(\mathrm{Re}=\mathrm{O})$, and



Fig. 1 The Raman spectra of: (a) Re/Al, (b) Re/ANN and (c) $\mathrm{Re} / \mathrm{SiO}_{2}-$ $\mathrm{Al}_{2} \mathrm{O}_{3}$ under ambient condition. 
$\delta_{\mathrm{a}, \text { as }}(\mathrm{O}-\mathrm{Re}-\mathrm{O})$, respectively (Fig. 1). Such results indicate that the surface rhenium oxide species on the prepared catalysts were presented in the form of isolated $\mathrm{ReO}_{4}$ structure. Additional strong Raman band at $815 \mathrm{~cm}^{-1}$ of the $\mathrm{Re} / \mathrm{SiO}_{2}-\mathrm{Al}_{2} \mathrm{O}_{3}$ was due to the interference from the $\mathrm{SiO}_{2}{ }^{8} \mathrm{~A}$ small band at around $600 \mathrm{~cm}^{-1}$ was detected for the Re/ANN catalyst and was assigned to the $\mathrm{Al}^{3+}$-oxygen symmetric stretching mode of the $\left[\mathrm{Al}\left(\mathrm{OH}_{2}\right)_{6}\right]^{3+}$ cation, which was resulted from the decomposition of $\mathrm{Al}\left(\mathrm{NO}_{3}\right)_{3} \cdot 9 \mathrm{H}_{2} \mathrm{O}$ precursor. ${ }^{19,20}$

The $\mathrm{Re} / \mathrm{Al}, \mathrm{Re} / \mathrm{ANN}$, and $\mathrm{Re} / \mathrm{SiO}_{2}-\mathrm{Al}_{2} \mathrm{O}_{3}$ differed largely on the nature of acidity (total amount, acid strength, and type of acidity). As shown by the $\mathrm{NH}_{3}$-TPD profiles in Fig. 2, the areas under the $\mathrm{NH}_{3}$-TPD profiles were in the order: $\mathrm{Re} / \mathrm{SiO}_{2}-\mathrm{Al}_{2} \mathrm{O}_{3}>$ $\mathrm{Re} / \mathrm{ANN}>\mathrm{Re} / \mathrm{Al}$. The Re/Al and the Re/ANN exhibited only weak and medium acidity whereas the $\mathrm{Re} / \mathrm{SiO}_{2}-\mathrm{Al}_{2} \mathrm{O}_{3}$ exhibited weak, medium, and strong acidity. The peak area for weak acidity of the Re/ANN was slightly higher than that of the Re/Al. The types of surface acidity on these catalysts were elucidated by the in situ DRIFTS of adsorbed $\mathrm{NH}_{3}$ and the results are shown in Fig. 3 . The bands at 1280 and $1622 \mathrm{~cm}^{-1}$ assigned to adsorbed $\mathrm{NH}_{3}$ on Lewis acid sites and the bands at 1470 and $1686 \mathrm{~cm}^{-1}$ assigned to $\mathrm{NH}_{4}{ }^{+}$on Bronsted acid sites were detected for all the rhenium oxide catalysts. ${ }^{11,21-23}$ Additional broad bands at 1240, 1405, 1506, $1570 \mathrm{~cm}^{-1}$ were assigned to $\mathrm{NH}_{2}$ vibration..$^{23-25}$ The amounts of Bronsted and Lewis acid sites calculated from the integrated peak areas based on the in situ DRIFTS results are given in Table 1 . The areas of Lewis acid sites at $1280 \mathrm{~cm}^{-1}$ were in the order: $\mathrm{Re} / \mathrm{SiO}_{2}-\mathrm{Al}_{2} \mathrm{O}_{3}>\mathrm{Re} / \mathrm{ANN}>\mathrm{Re} / \mathrm{Al}$ whereas and opposite trend was found for another Lewis acid sites at $1622 \mathrm{~cm}^{-1}$. The area for the Bronsted acid sites at $1470 \mathrm{~cm}^{-1}$ of the $\mathrm{Re} / \mathrm{SiO}_{2}-\mathrm{Al}_{2} \mathrm{O}_{3}$ catalyst was much larger than the Re/ANN and $\mathrm{Re} / \mathrm{Al}$ catalysts. Such results suggest that additional strong acidity observed in the $\mathrm{NH}_{3}$-TPD profiles for the $\mathrm{Re} / \mathrm{SiO}_{2}-$ $\mathrm{Al}_{2} \mathrm{O}_{3}$ were strong Bronsted acid sites.

The relative strength of Bronsted and Lewis acid sites present on the different catalysts was compared by the in situ DRIFTS of thermodesorption of $\mathrm{NH}_{3}$ experiments (Fig. 4). It was found that the bands corresponding to the Bronsted acid sites on Re/ANN and Re/Al markedly decreased with increasing temperature starting from $100{ }^{\circ} \mathrm{C}$ whereas those of $\mathrm{Re} / \mathrm{SiO}_{2}-$

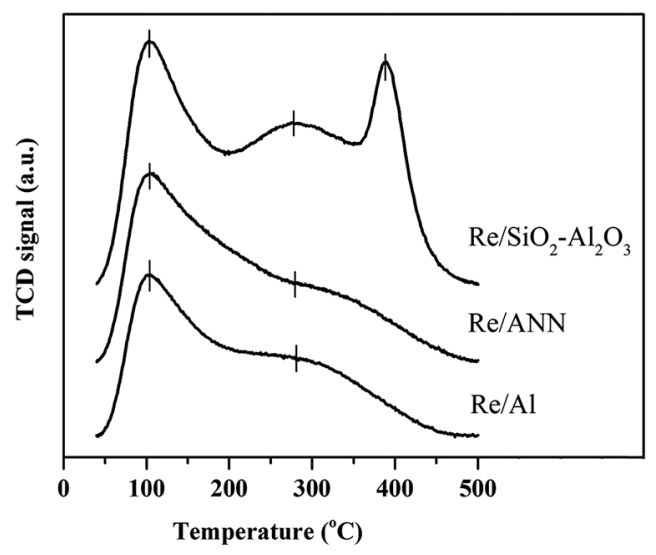

Fig. $2 \mathrm{NH}_{3}$-TPD profiles of different catalysts.

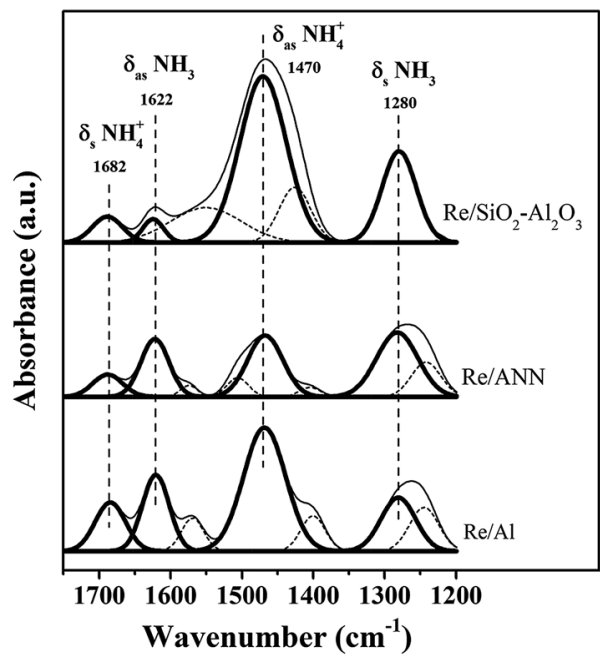

Fig. 3 The in situ DRIFTS substracted spectra of the chemisorbed ammonia over the catalysts at $60^{\circ} \mathrm{C}$.

$\mathrm{Al}_{2} \mathrm{O}_{3}$ started to decrease after the temperature was raised to above $250{ }^{\circ} \mathrm{C}$. In the present work, the fractions of weak and strong Bronsted and Lewis acid sites were calculated from subtracted peak areas of the in situ DRIFTS of $\mathrm{NH}_{3}$ thermodesorption results as summarized in Table 2 . The peak areas in the temperature range lower and above $250{ }^{\circ} \mathrm{C}$ were assigned to weak and strong acid sites, respectively. The fractions of weak and strong Lewis acid sites on all the catalysts were not significantly different. The fraction of Bronsted acid sites on the Re/ ANN and Re/Al catalysts inclined to the weak acid while most of the Bronsted acid sites on the $\mathrm{Re} / \mathrm{SiO}_{2}-\mathrm{Al}_{2} \mathrm{O}_{3}$ catalyst was classified as strong acid.

\subsection{Reaction results}

The supported rhenium oxide catalysts with different acid properties were employed in the metathesis reaction using various reactants including 2-pentene and ethylene $\left(2-\mathrm{C}_{5}+\mathrm{C}_{2}\right)$, pure 2-pentene $\left(2-\mathrm{C}_{5}\right), 2$-butene and ethylene $\left(2-\mathrm{C}_{4}+\mathrm{C}_{2}\right)$, pure 2-butene $\left(2-\mathrm{C}_{4}\right)$, and pure 1-butene $\left(1-\mathrm{C}_{4}\right)$ at $60{ }^{\circ} \mathrm{C}, 1 \mathrm{~atm}$, and WHSV $1.7 \mathrm{~h}^{-1}$. The yield of propylene of the catalysts with various feedstocks after $8 \mathrm{~h}$ reaction time are shown in Fig. 5. From the results, it was found that for a given set of reactants, the $\mathrm{SiO}_{2}-$ $\mathrm{Al}_{2} \mathrm{O}_{3}$ supported $\mathrm{Re}_{2} \mathrm{O}_{7}$ catalysts gave much higher yield of propylene than the $\mathrm{Al}_{2} \mathrm{O}_{3}$ supported ones. The yields of propylene obtained from the $\mathrm{Re} / \mathrm{SiO}_{2}-\mathrm{Al}_{2} \mathrm{O}_{3}$ were in order: $2-\mathrm{C}_{4}+\mathrm{C}_{2}>2-\mathrm{C}_{5}+$ $\mathrm{C}_{2}>1-\mathrm{C}_{4}>2-\mathrm{C}_{4}>2-\mathrm{C}_{5}$. On the other hand, the $\mathrm{Re} / \mathrm{ANN}$ and $\mathrm{Re} / \mathrm{Al}$ produced the highest propylene yield when $2-\mathrm{C}_{5}$ and $\mathrm{C}_{2}$ were used as the reactants under the reaction conditions used with the Re/ANN exhibited higher propylene yield than the Re/Al. The distribution of products obtained from various feedstocks over the $\mathrm{Re} / \mathrm{SiO}_{2}-\mathrm{Al}_{2} \mathrm{O}_{3}, \mathrm{Re} / \mathrm{ANN}$, and $\mathrm{Re} / \mathrm{Al}$ are shown in Fig. 6. The major reactions involved in the propylene production from various feedstocks are shown below in eqn (1) to (9).

Primary metathesis reactions

$$
\text { 2-Butene }+ \text { ethylene } \rightarrow \text { 2(propylene) }
$$


Table 1 The amounts of Bronsted and Lewis acid sites over the catalysts determined from the in situ DRIFTS of adsorbed $\mathrm{NH}_{3}$ at $60{ }^{\circ} \mathrm{C}$ after pretreatment

\begin{tabular}{llllll}
\hline Catalyst & $\begin{array}{l}\text { Bronsted acid (a.u.) } \\
\left(1682 \mathrm{~cm}^{-1}\right)\end{array}$ & $\begin{array}{l}\text { Lewis acid (a.u.) } \\
\left(1622 \mathrm{~cm}^{-1}\right)\end{array}$ & $\begin{array}{l}\text { Bronsted acid } \\
(\text { a.u. })\left(1470 \mathrm{~cm}^{-1}\right)\end{array}$ & $\begin{array}{l}\text { Lewis acid (a.u.) } \\
\left(1280 \mathrm{~cm}^{-1}\right)\end{array}$ & $\begin{array}{l}\text { Lewis acid (1280 } \\
\left.\mathrm{cm}^{-1}\right) /\left(1622 \mathrm{~cm}^{-1}\right)\end{array}$ \\
\hline $\mathrm{Re} / \mathrm{SiO}_{2}-\mathrm{Al}_{2} \mathrm{O}_{3}$ & 3.5 & 2.2 & 35.4 & 14.2 & 6.4 \\
$\mathrm{Re} / \mathrm{ANN}$ & 3.0 & 7.4 & 10.9 & 12.1 & 1.6 \\
$\mathrm{Re} / \mathrm{Al}$ & 6.7 & 9.3 & 21.9 & 8.4 & 0.9
\end{tabular}

$$
\begin{aligned}
& \text { 2-Pentene }+ \text { ethylene } \rightarrow \text { propylene }+1 \text {-butene } \\
& \text { 2-Pentene }+2 \text {-pentene } \rightarrow \text {-butene }+3 \text {-hexene } \\
& \text { 1-Butene }+1 \text {-butene } \rightarrow \text { ethylene }+3 \text {-hexene }
\end{aligned}
$$

Isomerization reaction

$$
\begin{aligned}
& \text { 1-Butene } \rightarrow \text { 2-butene } \\
& \text { 2-Butene } \rightarrow \text { 1-butene }
\end{aligned}
$$

Secondary metathesis reactions

$$
\begin{gathered}
\text { 2-Butene }+1 \text {-butene } \rightarrow \text { propylene }+2 \text {-pentene } \\
\text { 2-Pentene }+1 \text {-butene } \rightarrow \text { propylene }+3 \text {-hexene } \\
2 \text { (Hexenes) } \rightarrow \text { 2-butene }+\mathrm{C}_{7+}
\end{gathered}
$$

According to the stoichiometry of reaction, the mixed ethylene and 2-butene provides the highest yield of propylene. Using this feed, the $\mathrm{Re} / \mathrm{SiO}_{2}-\mathrm{Al}_{2} \mathrm{O}_{3}$ exhibited high metathesis activity for the cross-metathesis of ethylene and 2-butene (eqn (1)), producing propylene as the major product with very low amount of isomerization side reaction products. Surprisingly, little propylene was produced when using the mixed ethylene and 2-butene feedstocks on the Re/ANN and the Re/Al catalysts. It is likely that only the self metathesis of 2-butene occurred on the alumina-supported rhenium oxide catalysts under the reaction conditions used.

Using mixed ethylene and 2-pentene as the feedstocks, the major product selectivity obtained on the $\mathrm{Re} / \mathrm{SiO}_{2}-\mathrm{Al}_{2} \mathrm{O}_{3}$ were propylene and 2-butene with 1-butene, hexenes, and $\mathrm{C}_{7+}$ as the minor products. On the contrary, on the Re/Al and the Re/ANN, 2-butene and hexenes were the main products with lower selectivity to propylene and 1-butene. From the product distribution results, it reveals that both cross metathesis of ethylene
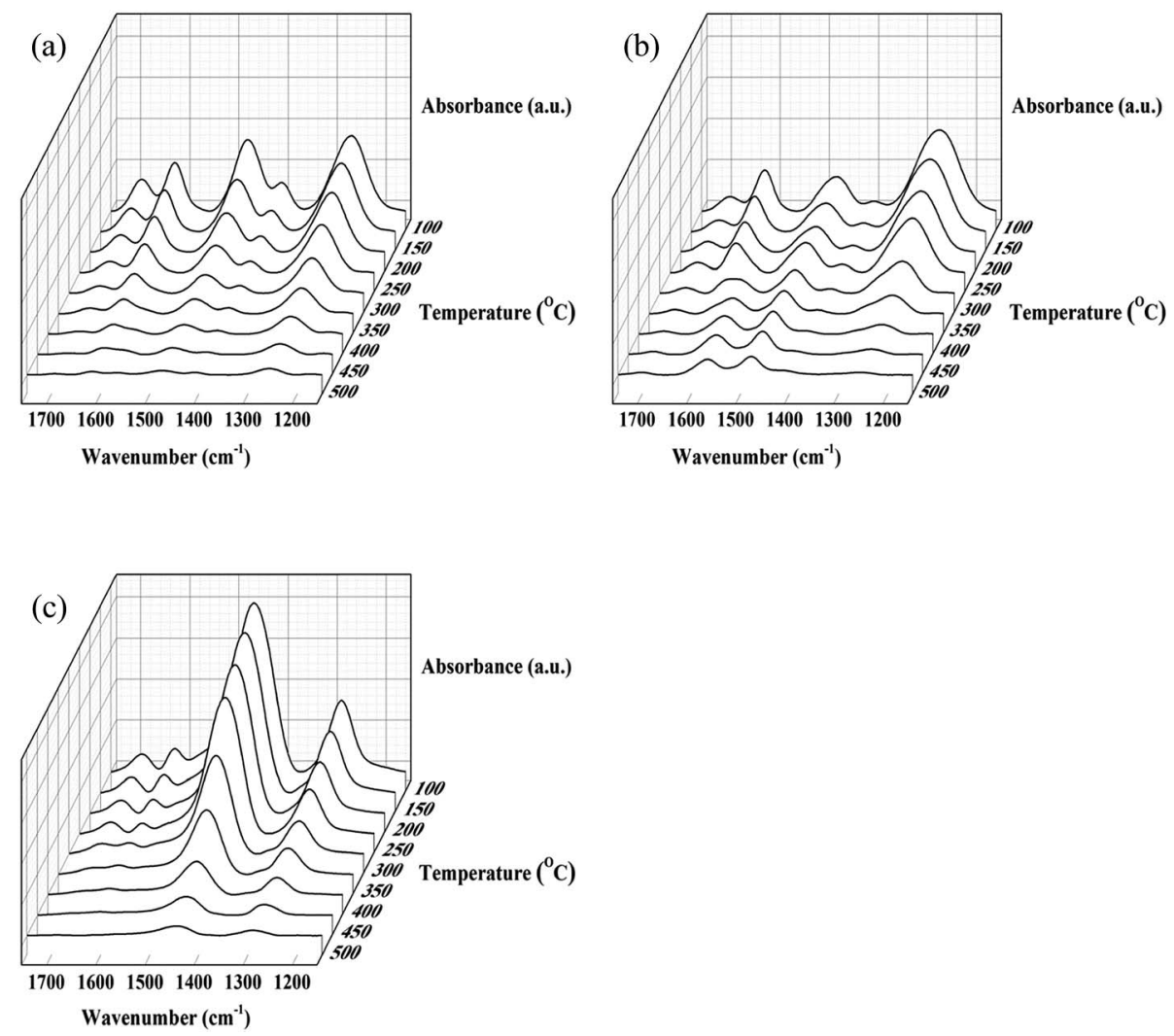

Fig. 4 The in situ DRIFTS of $\mathrm{NH}_{3}$ adsorption spectra with increment of temperature: (a) $\mathrm{Re} / \mathrm{Al}$, (b) $\mathrm{Re} / \mathrm{ANN}$ and (c) $\mathrm{Re} / \mathrm{SiO}{ }_{2}-\mathrm{Al}_{2} \mathrm{O}_{3}$. 
Table 2 The fraction of strength of the Bronsted and Lewis acid sites determined from the in situ DRIFTS of $\mathrm{NH}_{3}$ thermodesorption

\begin{tabular}{|c|c|c|c|c|c|c|c|c|}
\hline \multirow[b]{2}{*}{ Catalyst } & \multicolumn{2}{|c|}{$\mathrm{BA}\left(1682 \mathrm{~cm}^{-1}\right)$} & \multicolumn{2}{|c|}{ LA $\left(1622 \mathrm{~cm}^{-1}\right)$} & \multicolumn{2}{|c|}{$\mathrm{BA}\left(1470 \mathrm{~cm}^{-1}\right)$} & \multicolumn{2}{|c|}{ LA $\left(1280 \mathrm{~cm}^{-1}\right)$} \\
\hline & Weak & Strong & Weak & Strong & Weak & Strong & Weak & Strong \\
\hline Re/ANN & 49 & 51 & 47 & 53 & 61 & 39 & 55 & 45 \\
\hline $\mathrm{Re} / \mathrm{Al}$ & 79 & 21 & 63 & 37 & 82 & 18 & 55 & 45 \\
\hline
\end{tabular}

and 2-pentene (eqn (2)) and self-metathesis of 2-pentene (eqn (3)) occurred on all the catalysts. However, as suggested by Lwin et al.,$^{13}$ the rate-determining step of metathesis reaction is the rate of olefin adsorption and the adsorption rate increases

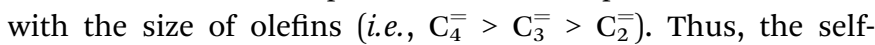
metathesis of 2-pentene may occur more easily than the crossmetathesis of ethylene and 2-pentene. In addition, due to the higher isomerization activity of the $\mathrm{Re} / \mathrm{SiO}_{2}-\mathrm{Al}_{2} \mathrm{O}_{3}$, 1-butene, which was one of the products from the cross-metathesis of ethylene and 2-pentene, was isomerized to 2-butene (eqn (5)) and further reacted with excess ethylene to produce augmentative propylene.

Using 2-butene as the single feedstock, the Re/Al and Re/ ANN were not active under the conditions used while the Re/ $\mathrm{SiO}_{2}-\mathrm{Al}_{2} \mathrm{O}_{3}$ produced propylene and 2-pentene as the main products. It is indicated that 2-butene was isomerized to 1-butene (eqn (6)) and then reacted with 2-butene to produce propylene and 2-pentene according to eqn (7) and (8). In the case of using 1-butene as the single feedstock, the Re/Al and Re/ ANN were active for the self-metathesis of 1-butene, forming ethylene and 3-hexene products (eqn (4)). Since propylene and 2-pentene were also observed, it is suggested that isomerization of 1-butene to 2-butene (eqn (5)) occurred on these catalysts and then further underwent the secondary metathesis reaction between 1-butene and 2-butene (eqn (7)). It should be noted that these catalysts were active enough to isomerization 1-butene to 2-butene but they could not isomerize 2-butene to 1-butene. From the product distribution results, the $\mathrm{Re} / \mathrm{SiO}_{2}-\mathrm{Al}_{2} \mathrm{O}_{3}$ appeared to be much more active than the $\mathrm{Al}_{2} \mathrm{O}_{3}$ supported ones. Additional propylene production was obtained from the

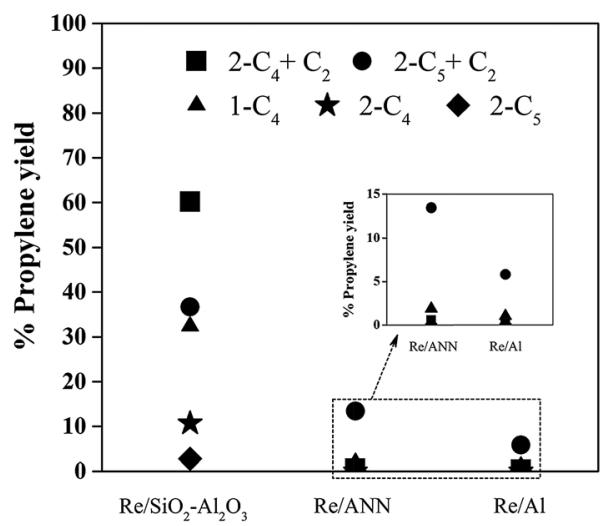

Fig. 5 The yield of propylene of the catalysts with various feedstocks at $8 \mathrm{~h}$ reaction time. cross metathesis of ethylene and 2-butene on the $\mathrm{Re} / \mathrm{SiO}_{2}-\mathrm{Al}_{2} \mathrm{O}_{3}$ (eqn (1)). Although propylene could not be obtained using 2-pentene as the single reactant, the catalysts were active enough to catalyze 2-pentene self-metathesis reaction, yielding 2-butene and 3-hexene (eqn (3)). And due to their much higher activity, the $\mathrm{Re} / \mathrm{SiO}_{2}-\mathrm{Al}_{2} \mathrm{O}_{3}$ exhibited additional side reactions self-metathesis of hexene, forming $\mathrm{C}_{7+}$ products (eqn (9)).

In summary, in order to produce propylene using pure feedstocks such as 1-butene and 2-butene, the catalyst must exhibit high isomerization activity to convert 1-butene to 2-butene and 2-butene to 1-butene in addition to high metathesis activity. Under the reaction conditions used, the isomerization of 1-butene to 2-butene occurred more easily than the isomerization of 2-butene to 1-butene.

\subsection{Activity-acidity relationship}

Due to the interference of the $\mathrm{SiO}_{2}$ bands in the Raman spectra, it was difficult to quantitatively determine the amount of active Re species on the $\mathrm{Re} / \mathrm{SiO}_{2}-\mathrm{Al}_{2} \mathrm{O}_{3}$ in order to compare with the $\mathrm{Al}_{2} \mathrm{O}_{3}$ supported ones. The catalyst performances in this study, thus, were correlated to the acidity presented. Nevertheless, it should be noted that acidity was arisen from both the rhenium oxide species and the supports themselves. Based on the $\mathrm{NH}_{3}$-IR results of the catalysts at $60{ }^{\circ} \mathrm{C}$ after pretreatment (Table 1), which represented the surface species before reaction, it was found that the Re/Al catalysts possessed significant amount of Bronsted acidity but they exhibited the lowest activity for both isomerization and metathesis reactions. It is suggested that the strength of acidity should be taken into account as well. From the calculated fractions of weak and strong Bronsted and Lewis acid sites based on the in situ DRIFTS of $\mathrm{NH}_{3}$ adsorption and thermodesorption results, only the $\mathrm{Re} / \mathrm{SiO}_{2}-\mathrm{Al}_{2} \mathrm{O}_{3}$ displayed emphatically strong Bronsted acidity. The Re/Al contained relatively high quantity of Bronsted acidity but most of them was weak acid. From these results, it is suggested that the strong Bronsted acidity was necessary for the isomerization of 2-butene to 1-butene. On the other hand, there were no differences in terms of the fractions of weak and strong Lewis acid among the prepared catalysts. A number of studies in the literature suggested that Lewis acidity plays significant role in metathesis reaction. ${ }^{11,21}$ The present work, however, revealed various Lewis acid sites with different bond strengths on the supported Re oxide catalysts. It was found that the higher ratios of the weak Lewis acid bands at wavenumber $1280 \mathrm{~cm}^{-1} / 1622$ $\mathrm{cm}^{-1}$ led to higher metathesis activity as observed in the order: $\mathrm{Re} / \mathrm{SiO}_{2}-\mathrm{Al}_{2} \mathrm{O}_{3} \gg \mathrm{Re} / \mathrm{ANN}>\mathrm{Re} / \mathrm{Al}$. From the reaction test results, the $\mathrm{Re} / \mathrm{SiO}_{2}-\mathrm{Al}_{2} \mathrm{O}_{3}$ showed high activity in all the 

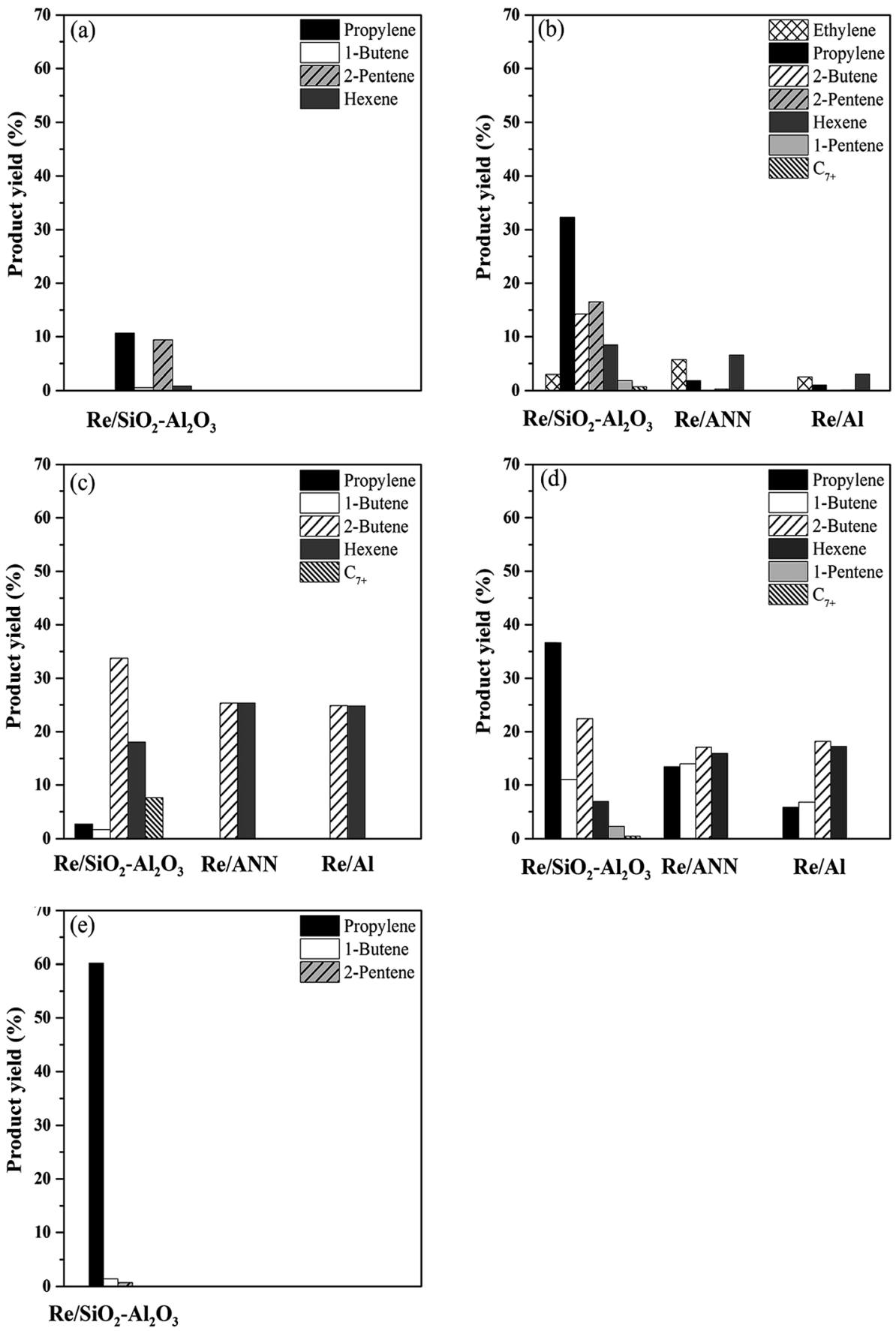

Fig. 6 Product distributions of various feedstocks over the catalysts: (a) pure 2-butene, (b) pure 1-butene, (c) pure 2-pentene, (d) mixed ethylene and 2-pentene and (e) mixed ethylene and 2-butene.

reactions necessary for propylene production from various feedstocks including isomerization of 2-butene to 1-butene and self- and cross-metathesis reactions, resulting in the highest yield of propylene. Therefore, to handle ethylenepropylene price fluctuation, supported rhenium oxide-based catalysts should possess certain weak Lewis acid species (high ratio of weak Lewis acid bands at wavenumber $1280 \mathrm{~cm}^{-1} / 1622 \mathrm{~cm}^{-1}$ ) and strong Bronsted acid sites. Generally, the role of $\mathrm{SiO}_{2}$ in $\mathrm{SiO}_{2}-\mathrm{Al}_{2} \mathrm{O}_{3}$ supported rhenium oxide catalysts has been related to the bridging of the silanol groups ( $\mathrm{Si}-\mathrm{OH})$ with the $\mathrm{Al}_{2} \mathrm{O}_{3}$ in the form of $\mathrm{Si}-\mathrm{OH}-\mathrm{Al}$. These bridging hydroxyl groups generate active rhenium sites while silanol groups would generate inactive rhenium sites..$^{3,5,26}$ The high olefins metathesis activity of $\mathrm{SiO}_{2}-\mathrm{Al}_{2} \mathrm{O}_{3}$ supported rhenium oxides thus could not be generalized for any $\mathrm{SiO}_{2}-\mathrm{Al}_{2} \mathrm{O}_{3}$ support since it was found to depend on many factors such as the $\mathrm{SiO}_{2}-\mathrm{Al}_{2} \mathrm{O}_{3}$ composition ${ }^{27}$ and the preparation method of $\mathrm{SiO}_{2}-\mathrm{Al}_{2} \mathrm{O}_{3} \cdot{ }^{17,28}$ 


\section{Conclusions}

The low loading $\mathrm{Re} / \mathrm{SiO}_{2}-\mathrm{Al}_{2} \mathrm{O}_{3}$ catalyst allows the production of propylene from various feedstocks. Under the reaction conditions used $\left(60{ }^{\circ} \mathrm{C}, 1 \mathrm{~atm}\right)$, the yield of propylene from different feeds was in the order: $2-\mathrm{C}_{4}+\mathrm{C}_{2}>2-\mathrm{C}_{5}+\mathrm{C}_{2}>1-\mathrm{C}_{4}>2-\mathrm{C}_{4}>2-\mathrm{C}_{5}$. The high metathesis activity was correlated well to the presence of high ratio of the Lewis acidity bands $\left(1280 \mathrm{~cm}^{-1} / 1622 \mathrm{~cm}^{-1}\right)$ in the form of weak Lewis acid. The strong Bronsted acidity, however, was necessary for the isomerization side reactions when using 2-butene or 1-butene as the single reactant in order to produce propylene from the cross metathesis of 1-butene and 2-butene. The results provide easy selection of feedstocks for propylene production when there is olefins price fluctuation.

\section{Acknowledgements}

The authors would like to thank the financial supports from the Grant for International Research Integration: Chula Research Scholar, Ratchadaphiseksomphot Endowment Fund and the Thailand Research Fund (BRG5780010 and IRG5780014). The Royal Golden Jubilee Ph.D. scholarship for S. V. from the Thailand Research Fund (TRF), SCG Chemicals, and the Office of Higher Education Commission is also gratefully acknowledged.

\section{References}

1 J. S. Plotkin, The Propylene Quandary, https:/www.acs.org/ content/acs/en/pressroom/cutting-edge-chemistry/the-propylenequandary.html, accessed August 8, 2016.

2 K. J. Ivin and J. C. Mol, Olefin Metathesis and Metathesis Polymerization, Academic Press, London, 1997.

3 J. C. Mol, Catal. Today, 1999, 51, 289-299.

4 J. C. Mol, J. Mol. Catal. A: Chem., 2004, 213, 39-45.

5 M. Sibeijn and J. C. Mol, Appl. Catal., 1990, 67, 279-295.

6 J. A. Moulijn and J. C. Mol, J. Mol. Catal., 1988, 46, 1-14.

7 A. Andreini, X. Xiaoding and J. C. Mol, Appl. Catal., 1986, 27, 31-40.

8 M. A. Vuurman, D. J. Stufkens, A. Oskam and I. E. Wachs, J. Mol. Catal., 1992, 76, 263-285.

9 S. Lwin, C. Keturakis, J. Handzlik, P. Sautet, Y. Li, A. I. Frenkel and I. E. Wachs, ACS Catal., 2015, 5, 1432-1444.
10 M. A. Vuurman and I. E. Wachs, J. Phys. Chem., 1992, 96, 5008-5016.

11 S. Vorakitkanvasin, S. K. N. Ayudhya, K. Suriye, P. Praserthdam and J. Panpranot, Appl. Catal., A, 2016, 517, 39-46.

12 S. Lwin, Y. Li, A. I. Frenkel and I. E. Wachs, ACS Catal., 2015, 5, 6807-6814.

13 S. Lwin and I. E. Wachs, ACS Catal., 2016, 6, 272-278.

14 B. C. Vicente, R. C. Nelson, A. W. Moses, S. Chattopadhyay and S. L. Scott, J. Phys. Chem. C, 2011, 115, 9012-9024.

15 X. Xiaoding, J. C. Mol and C. Boelhouwer, J. Chem. Soc., Faraday Trans. 1, 1986, 82, 2707-2718.

16 P. Amigues, Y. Chauvin, D. Commereuc, C. T. Hong, C. C. Lai and Y. H. Liu, J. Mol. Catal., 1991, 65, 39-50.

17 K. Bouchmella, P. Hubert Mutin, M. Stoyanova, C. Poleunis, P. Eloy, U. Rodemerck, E. M. Gaigneaux and D. P. Debecker, J. Catal., 2013, 301, 233-241.

18 P. Hodges, Propylene price collapse highlights New Normal world, http:/www.icis.com/blogs/chemicals-and-the-economy/ 2016/03/propylene-price-collapse-highlights-new-normalworld/, accessed 9 March, 2016.

19 W. W. Rudolph, R. Mason and C. C. Pye, Phys. Chem. Chem. Phys., 2000, 2, 5030-5040.

20 I. F. Myronyuk, V. I. Mandzyuk, V. M. Sachko and V. M. Gun'ko, Nanoscale Res. Lett., 2016, 11, 153.

21 F. Schekler-Nahama, O. Clause, D. Commereuc and J. Saussey, Appl. Catal., A, 1998, 167, 237-245.

22 G. Busca, G. Martra and A. Zecchina, Catal. Today, 2000, 56, 361-370.

23 H. Hu, S. Cai, H. Li, L. Huang, L. Shi and D. Zhang, J. Phys. Chem. C, 2015, 119, 22924-22933.

24 J. G. Amores, V. S. Escribano, G. Ramis and G. Busca, Appl. Catal., B, 1997, 13, 45-58.

25 X. Wang, W. Wu, Z. Chen and R. Wang, Sci. Rep., 2015, 5, 9766.

26 S. Lwin and I. E. Wachs, ACS Catal., 2014, 4, 2505-2520.

27 W. Phongsawat, B. Netiworaruksa, K. Suriye, P. Praserthdam and J. Panpranot, Catal. Lett., 2012, 142, 1141-1149.

28 W. Phongsawat, B. Netiworaruksa, K. Suriye, P. Praserthdam and J. Panpranot, J. Ind. Eng. Chem., 2014, 20, 145-152. 